\title{
How does Interest Rate Effect Exchange Rate of Pakistan: Evidence of ARDL Bound Testing Approach
}

\author{
Sajid Ali *
}

\begin{abstract}
The purpose of this paper is to examine the long run as well as the short run relationship between exchange rate and interest rate in the context of Pakistan. Annual time series data have been used over the period of 1980 to 2015. Augmented Dickey-Fuller (ADF) unit root test, Johansen and Jeuuselius's cointegration technique, auto regressive distributed lag (ARDL) bound testing model, error correction model (ECM), CUSUM and CUSUM of square tests for stability of model and, causality analysis in supporting variance decomposition are used to meet the research purpose. The study concluded the existence of a significant positive relationship between exchange rate and interest rate in the long run as well as in the short run in the context of Pakistan. These results are consistent with theoretical aspects. It is suggested that Pakistan should form economic, policies, especially monetary policy, keeping view the relationship between exchange rate and interest rate.
\end{abstract}

Keywords: Exchange Rate, Interest Rate, Auto regressive distributed lag Bound testing model (ARDL) and error correction model (ECM) analysis.

\section{Introduction}

In the current era of economic competition, monetary policy is significant for the economic growth of any country and vital tools of monetary policy are exchange rate and interest rate, both play important role in the economic development of any country. The purpose of the study is to explore the short-run and long-run relationship between these two variables.

History of Pakistan's exchange rate policy stated as from 1947 to 1970 Pakistani rupee was associated with British pound sterling after separation of East Pakistan shifted to US dollar following the fixed exchange rate policy from 1971 to 1981 . After a significant depreciation of $38.5 \%$ in Pakistani rupee, then managed floating policy was adapted from 1982 to 1999, in 1998 due to the nuclear tests Pakistani economy faced a severe depression again Pakistani rupee was depreciated. After 9/11 the whole world situation changed and Pakistan adopted free floating exchange rate policy from 2000 to present.

In the economic development of any country, both exchange rate and interest rate have a significant role, to control monetary policy there are significant tools. In past many

\footnotetext{
* Department of Business Administration, Iqra University, Karachi-75300, Pakistan.

E-mail: sajidalikk@live.com
} 
studies have been accomplished regarding; Association between exchange rate and interest rate differentials, results has been found consistent with theories of economics as negative relationship with constant price and positive relationship in the long run with flexible price, except insignificant with the real interest rate (Scott Hacker, Karlsson, \& Maansson, 2012; Narayan \& Smyth, 2006).

Some researchers predict the relationship between post-Keynesian v/s neoclassical explanations on exchange rate movement and investigate the effect of exchange rate variation on price and output and find the result in favor of neoclassical approach, conclude that probable fluctuation has insignificant effect on price and output and It is recommended that monetary policy should be purpose to decrease the wide-ranging variation in exchange rate (Harvey, 2005; Kandil \& Mirzaie, 2005). Explore the impact of productivity shocks on nominal exchange rate variability and investigate the effect of black market exchange rate on the stability of money demand in Pakistan. Variation in nominal exchange rates is explained by productivity differentials in both tradable and non-tradable sector and results also support the theory of research and find the long-term relationship among black market exchange rate, inflation, money demand and income (Zakaria \& Ahmad, 2009; Rehman \& Afzal, 2003).

However, in the context of Pakistan, many studies have been conducted in past regarding exchange rate with different variables and other economic indicators. The central purpose of this research is empirical to analyze the short-run and long-run association between exchange rate and interest rate through ARDL Bound testing and ECM in the context of Pakistan by using the annual time series data for 36 years from 1980 to 2015 .

- What is the long-run and the short-run relationship between exchange rate and interest rate in the framework of Pakistan?

This study consists of five sections, following the introduction, Section 2 consists of literature reviews of selected studies, research model is formulated in Section 3, the result of all estimations are discussed in Section 4 and the conclusion is discussed in Section 5.

\section{Literature Review}

\section{Theoretical Background}

Fisher Effect indicates a positive relationship between a country's nominal interest rate and its price level or inflation, explained how the nominal interest rate is affected by growth in money in the long run, but no effect on real interest rate, as the growth in money increases inflation which also affects the nominal interest rate positively.

Purchasing Power Parity: according to this theory of exchange rate a unit of any currency can buy the same quantity of goods in any part of the world, this theory is based on the principle of one price. How this law applies in the international market, suppose One rupee could buy more coffee in Pakistan than Japan, international traders will purchase 
coffee from Pakistan and can export it to Japan. On the other hand, one rupee could buy more coffee in Japan than Pakistan, and then traders can purchase coffee in Japan and will import it to Pakistan.

According to Johan Maynard Keynes, Purchasing Power Parity and Fisher Effect are only applicable in the long run with a flexible price. But with sticky price asset approach is applicable. Interest Parity proved the association between interest rate and exchange rate, as a rise in interest rate is followed by exchange rate, reduce in exchange rate, leads to appreciation in the value of home currency like rupee and decrease in interest rate is followed by rise in exchange rate, leads to depreciation in the value of home currency (Mankiw, 2004).

Exchange rate as a tool of monetary policy:

Depreciation effect: if the exchange rate decreases as a result price of exports reduces and price of imports increases, exports become more competitive in international markets and imports become less competitive in the local market, so depreciation of currency could be good for the country, but it could also increase inflation in the country, if its production capacity can meet the demand of the market. China and Japan are the best examples.

Appreciation effect: if the exchange rate increases, as a result, exports become more expensive as compare to other countries in the international market and imports become inexpensive in the local market as compare to local products it might not be good for the country in a given situation but it is the technique to control inflation.

If it is the policy of the government to use the interest rate as an instrument, it may be either changing composition of interest rate or broad level of interest rate. Long term rate may be possibly controlled by raising or decreasing the PSBR (Public sector borrowing requirements). Short term rate may be possibly controlled through open market operation in the discount market. It is suggested that short-term rate policy should be used as a monetary policy tool.

\section{Empirical Studies}

We need an extensive literature review to support and for further confirmation of the relationship between our focused variables, on the basis of previous studies we can analyze either result are supported or not.

According to previous researchers, such as Scott Hacker et al. (2012) investigate the relationship between exchange rates and interest rate disparity and the negative relationship is examined in the short run and positive relationship is found in the long-run between the focused variables. Greenaway, Kneller, and Zhang (2012) investigated the exchange rate's effect on firm exports and FDI role in the United Kingdom manufacturing Industry and multinational firms of EU and outside the EU, established that firms' export participation decisions are not significantly associated to exchange rate movements but it has a significant negative effect on the export share of the firms after entry. Multinational firms originating outside the EU are less affected than inside EU firms by the movements of exchange rates. Colantone (2012) inspects effect of real exchange rates and trade openness on job reallocation and found that real appreciation has a negative impact on net employment 
growth while job creation is not significantly affected but it is also suggested Belgium is a small open economy.

Zakaria and Ahmad (2009) explore the effects on the nominal exchange rate inconsistency of production shocks in Pakistan, find that deviation in nominal exchange rates is explicated by productivity differentials in both trading and non-trading sector and results also support the theory of research. Duttagupta and Tolosa (2007) estimated that agencies having fixed exchange rate can earn larger incentive to spend than other exchange rate regimes, depending on the agency's ability to capability the cost. Such behavior is not possible in the flexible regime. After that empirically, fiscal stances are more freely riding in regimes with fixed pegs and currency union than flexible regimes. Lewis (2007) primary discovers the real appreciation of the dollar because of a little but significant involvement of the Balassa-Samuelson result over the specified time period 1981-2003, supplementary production upset illustrate the deviation in the euro-dollar exchange rate but are less essential than nominal and demand shocks. Baldwin and Yan (2007) concluded that pace of regulation of Canadian and United States prices is much less overstated by industry features related to the production scale, import penetration and the grade of product discrimination between home and overseas imported products. Taguchi (2007) analyzes the impact of financial crisis on selected countries with the help of exchange rate management in the four East Asian countries post-financial crisis, predicted Philippines and Korea might reduce US dollar dominance while Korea and Indonesia might raise the weight to the Japanese Yen and Euro.

Machnes (2006) examines that there is considerably association in the expected future scale of spot exchange rate and trading volume of call and put options and business volume of put-to call options. This association is inversely related to the time frame as more time is passed weaker the association will be than before. Dealers approaches are inconsistent with the outcomes of this research. Previous studies have proven the role of options business volume in the prediction of spot exchange rate. Narayan and Smyth (2006) analyze the positive long run relationship among all three variables has been found except insignificant relationship has been found with the real interest rate. But the short run relationship is significant and non-monotonic. Groen (2005) investigates that major exchange rates have demonstrated an appropriate low-frequency co-movement with corresponding monetary fundamentals, mostly we assume that the behavior of Germany based monetary fundamentals has been suitable for both the pre-1999 and post-1999 period as EMU (European Monetary Union). Kandil and Mirzaie (2005) observe the exchange rate fluctuations effects on output and price, found that anticipated exchange rate movement has less effect on output and price level whereas unanticipated fluctuation in exchange rate has a significant effect on output and price level in many developing countries. It is recommended that monetary policy should aim to reduce the wide-ranging variation in exchange rate. Azid, Jamil, Kousar, and Kemal (2005) examine the positive but insignificant support of the position that the excessive movements of the exchange rate have pronounced effect on the manufacturing production, the concerns of policy makers about the cost of flexible exchange rate are not accepted by the result. Bahmani-Oskooee and Goswami 
(2005) explores that domestic and foreign price levels are not weakly exogenous in many countries. Larsson (2004) investigates the affiliation of Swedish real exchange rate with other currency regimes like Germany, this study is concluded with the support of Unit root test, cointegration, and ECM that there is long term association (cointegration) between real exchange rate and productivity of Sweden and Germany. But at the same time in the short run, the exchange rate regime has subjected for the dynamics of the real exchange rate. But in the long run, equilibrium have been attended immediately as the exchange rate is floating freely.

Li (2004) found that real exchange rates depreciate after trade liberalization for the countries having multiple liberalizations, but exchange rates do not depreciate in an early stage. It is suggested that partial liberalization prevents adjustments toward the equilibrium of exchange rate. Rehman and Afzal (2003) concluded that there is cointegration among M2 and income, inflation rate and black market exchange rate and find a stable relation for M2. Helmut (2003) examines the nonlinear association between exchange rate indecision, the impact of exchange rate deviation on trade growth is found to be weak. When there is out sized variation in the exchange rate as the result there is conditioning gain in trade growth and empirical results are in favor of the view that might be a nonlinear relationship of interest. Furthermore, lacks homogeneity across countries and imports vs. exports. Peridy (2003) finds the result as, the effect of exchange rate fluctuation on export differ significantly, accordingly industry and target market or country. As a result, divisional and geographical both this prejudice are found when analyzing the response of exports of G-7 countries to exchange rate fluctuation. Rahman and Basher (2001) analyze the exchange rate disorders and real exchange rate performance in the framework of Bangladesh from the period 1977 to 1998 discover that Bangladeshi currency Taka was overvalued during the late seventies and eighties but was in equilibrium during nineties. Devaluation process was adopted by most of the trading allies to preserve the real exchange equilibrium, resulting Taka was also devalued. Ahmad and Ali (1999) estimates the association between price level and the exchange rate is bidirectional and impact of inflation on devaluation is larger than the impact of devaluation on inflation. For policy formulations, both these focused variables are interrelated and are vital tools for monetary policy.

After extensive literature review, we found mix results, most of the studies are supporting a long-run relationship between interest rate and exchange rate, but in the case of short-run relationship results are mixed. So for further confirmation, we need to estimate the relationship between these two variables.

\section{Methodology}

In accordance with the previous studies, the model to investigate the long run as well as the short run relationship between exchange rate and interest rate in the context of Pakistan, following framework is used: 


$$
L E R_{t}=\alpha_{0}+\beta_{1} I R_{t}+\beta_{2} G D P_{t}+\beta_{3} C P I_{t}+\epsilon_{t}
$$

Whereas LER represents the log of the exchange rate between PKR and USD, IR represents interest rate, GDP economic growth and CPI represents inflation, $(\alpha)$ is constant, $(\beta)$ for coefficients, e is error term and t for time series data. In this model exchange rate and interest rate are focused variables, whereas other are control variables.

\section{Unit Root Analysis}

Augmented Dickey Fuller (ADF) unit root tests is applied to examine the stationary properties for long-term connection of given time series data.

$$
\Delta Y_{t}=\alpha_{0}+\alpha_{1} Y_{t-1}+\sum_{j=1}^{k} d_{j} \Delta Y_{t-j}+\epsilon_{t}
$$

Where $\Delta$ is first difference operator, $\epsilon_{t}$ is a pure white noise error term, $\alpha_{0}$ is a constant number in the equation, $k$ is the maximum number of lag of criterion variable and $\mathrm{Y}_{t}$ is a series of time. Dickey and Fuller (1979) test is used to investigate whether the estimations are equivalent to zero or not. This test gives the collective distribution of Augmented Dickey Fuller statistics. The variable is called stationary, if the coefficient value $\alpha_{1}$ is less than the critical values from statistics table.

\section{Cointegration Analysis}

To study the long-run relationship between focused variables, we used the autoregressive distributed lag (ARDL) method of co-integration established by (Pesaran \& Shin, 1998; Pesaran, Shin, \& Smith, 2000, 2001). ARDL approach has preference over other cointegration methods because ARDL can be used regardless of whether selected variables are stationary at I(0), I(1) or mutually co-integrated (Pesaran \& Shin, 1998). The ARDL method has better estimated for small sample properties (Haug, 2002; Shah, 2016; Sharif, Raza, et al., 2016). Regardless explanatory variable is endogenous even then in ARDL method, the estimations may be performed (Pesaran \& Shin, 1998; Pesaran et al., 2001, 2001). The ARDL model is developed for estimations as follows:

$$
\begin{array}{r}
\Delta L E R_{t}=\psi_{0}+\psi_{1} \sum_{i=1}^{p} \Delta I R_{t-1}+\psi_{2} \sum_{i=1}^{p} \Delta G D P_{t-1}+\psi_{3} \sum_{i=1}^{p} \Delta C P I_{t-1} \\
+\psi_{4} \sum_{i=1}^{p}+\gamma_{1} I R_{t-1}+\gamma_{2} G D P_{t-1}+\gamma_{3} C P I_{t-1}+\mu_{t}
\end{array}
$$

Whereas $\psi$ represents constant and $\mu$ denotes error term and the error correction dynamics are denoted by the summation sign while the second part of the equation corresponds to the long-run relationship. The null hypothesis of no cointegration is rejected if 
the calculated F-test statistics exceeds the upper critical bound (UCB) value. The results are said to be inconclusive if the F-test statistics fall between the upper and lower critical bound. Lastly, the null hypothesis of no cointegration is accepted if the F-statistics is below the lower critical bound (Nathan, Liew, \& Wong, 2016; Arif \& Suleman, 2017).

$$
L E R_{t}=\zeta_{0}+\zeta_{1} \sum_{i=1}^{p} I R_{t-1}+\zeta_{2} \sum_{i=1}^{p} G D P_{t-1}+\zeta_{3} \sum_{i=1}^{p} C P I_{t-1}+\mu_{t}
$$

\section{Error Correction Model}

After confirmation of long-run relationship, ECM (Error Correction Model) is used to estimate the short run relationship among selected variables, according to given results of ECM, error correction term has significant probability with negative coefficient which is the confirmation of short run relationship among selected variables.

$$
\Delta L E R_{t}=\varphi_{0}+\varphi_{1} \sum_{i=1}^{p} \Delta I R_{t-1}+\varphi_{2} \sum_{i=1}^{p} \Delta G D P_{t-1}+\varphi_{3} \sum_{i=1}^{p} \Delta C P I_{t-1}+n E C T_{t-1}+\mu_{t}
$$

\section{Results and Estimation}

The basic purpose of this study to examine the relationship between exchange rate and interest rate of Pakistan in long run as well as in short run for this purpose also used control variables like gross domestic product and inflation. World Bank and State Bank of Pakistan are the main sources of data collection of all variables. To find out the relationship between exchange rate and interest rate of Pakistan, statistical techniques used are the ordinary least square technique in regression analysis, Augmented Dickey-Fuller (ADF) unit root test to check stationary properties of data and to examine long run relationship between observed variables Johansen and Juselius Cointegration for further confirmation ARDL Bound testing is also applied, Error Correction (ECM) is used to analyze short-run relationship and Granger Causality is used to estimate the cause and effect of focused variables.

\section{Stationary Analysis}

Stationary properties of time series data have been analyzed by Augmented Dickey-Fuller (1979) unit root test. Results are exhibited in the following Table:1 as all considered variables are stationary at first difference. It means all variables do not have the problem of unit root and are stationary at a critical level of $1 \%, 5 \%$, and $10 \%$. 
Table 1

Stationary Test Results

\begin{tabular}{ccccccccc}
\hline Variables & \multicolumn{8}{c}{ ADF test } \\
\cline { 2 - 9 } & \multicolumn{9}{c}{$\mathbf{I}(\mathbf{0})$} & \multicolumn{5}{c}{$\mathbf{I}(\mathbf{1})$} \\
\cline { 2 - 9 } LER & -1.781 & 0.383 & -1.21 & 0.893 & -4.803 & 0.001 & -5.309 & 0.001 \\
\hline CPI & -2.633 & 0.097 & -2.594 & 0.285 & -6.894 & 0.000 & -6.781 & 0.000 \\
\hline IR & -1.528 & 0.508 & -1.465 & 0.823 & -4.792 & 0.001 & -4.844 & 0.002 \\
\hline GDP & 2.239 & 1.000 & 0.076 & 0.996 & -5.103 & 0.000 & -5.885 & 0.000 \\
\hline
\end{tabular}

After confirmation of stationary properties of all selected variables of the model, so move forward for further estimation.

$H a_{1}$ : There is a significant relationship between exchange rate and Interest rate of Pakistan during long runs.

\section{Long Run Relationship Analysis}

\section{Cointegration}

To explore out the long run relationship between considered variables Johansen and Juselius (1990) cointegration test has been used. Trace statistics and Max. Eigen Statistics have been applied to predict cointegration. Table:2 explained the calculated values of these two tests. Test hypothesis is there is no cointegration between the selected variables is rejected by the estimated values and the long run relationship is found among our model variables at a significance level of $5 \%$.

Table 2

Cointegration test results

\begin{tabular}{ccccccc}
\hline Null Hypothesis & Trace & 5\% critical values & Prob. & Max.Eigen.Value & 5\% critical values & Prob. \\
\hline None & 59.254 & 55.246 & 0.021 & 33.875 & 30.815 & 0.021 \\
At most 1 & 25.375 & 35.011 & 0.362 & 14.335 & 24.252 & 0.557 \\
At most 2 & 11.041 & 18.398 & 0.386 & 9.724 & 17.148 & 0.423 \\
\hline
\end{tabular}

Source: Author's estimations

The above results suggest that there is a long-run relationship between exchange rate and interest rate of Pakistan. The Long run relationship between observed variables is supported by Fisher Effect and Purchasing Power Parity theory.

To analyze the long run relation between IR (Interest Rate) and LER (Exchange Rate) Auto Regressive Distributed Lag (ARDL) test is used, above result shows there is a significant impact of Interest Rate on Exchange Rate of Pakistan but with negative coefficients. Bound Test confirms the long run relation among selected variables of Pakistan as value of F-Statistic that is (7.37) greater than Critical values (I1) upper bound at any significant level, in next table results of long run Cointegration are disclosed, according to given results 
there is a negative long-term relationship between interest rate and exchange rate as an interest rate is significant and negative coefficient in table: 4, rejecting the null hypothesis of no Cointegration.

Table 3

Bound Testing

\begin{tabular}{lcc}
\hline Test Statistic & Value & K \\
\hline F-statistic & 7.370 & 3.000 \\
\hline Critical Value Bounds & & \\
\hline Significance & I0 Bound & I1 Bound \\
\hline $10 \%$ & 2.720 & 3.770 \\
$5 \%$ & 3.230 & 4.350 \\
$3 \%$ & 3.690 & 4.890 \\
$1 \%$ & 4.290 & 5.610 \\
\hline Source: Author's estimations & &
\end{tabular}

Table 4

ARDL

\begin{tabular}{|c|c|c|c|c|}
\hline Variable & Coefficient & Std. Error & t-Statistic & Prob.* \\
\hline $\operatorname{LER}(-1)$ & 0.562 & 0.123 & 4.552 & 0.000 \\
\hline $\operatorname{LER}(-2)$ & 0.026 & 0.123 & 0.210 & 0.836 \\
\hline $\operatorname{LER}(-3)$ & 0.365 & 0.168 & 2.178 & 0.043 \\
\hline IR & -0.007 & 0.003 & -2.362 & 0.030 \\
\hline $\operatorname{IR}(-1)$ & 0.002 & 0.006 & 0.404 & 0.691 \\
\hline $\operatorname{IR}(-2)$ & 0.011 & 0.007 & 1.677 & 0.111 \\
\hline CPI & 0.007 & 0.003 & 2.176 & 0.043 \\
\hline CPI $(-1)$ & 0.005 & 0.003 & 1.465 & 0.160 \\
\hline CPI(-2) & -0.002 & 0.003 & -0.684 & 0.503 \\
\hline CPI $(-3)$ & -0.003 & 0.002 & -1.986 & 0.063 \\
\hline CPI(-4) & 0.011 & 0.004 & 2.455 & 0.025 \\
\hline GDP & -0.003 & 0.001 & -2.598 & 0.018 \\
\hline $\operatorname{GDP}(-1)$ & 0.003 & 0.001 & 3.698 & 0.002 \\
\hline $\mathrm{C}$ & 0.083 & 0.064 & 1.287 & 0.215 \\
\hline Adjusted $R^{2}$ & \multicolumn{4}{|c|}{0.996} \\
\hline F-statistic(Prob) & \multicolumn{4}{|c|}{$642.0826(0.000)$} \\
\hline Durbin-Watson stat & \multicolumn{4}{|c|}{2.306} \\
\hline
\end{tabular}

Source: Author's estimations

$\mathrm{Ha}_{2}$ : There is a significant relationship between exchange rate and Interest rate of Pakistan in short run.

\section{Short Run Relationship}

After confirmation of long-run relationship, ECM (Error Correction Model) is used to estimate the short run relationship among selected variables, according to given results of ECM, error correction term there is not any short-run relationship between exchange rate and interest rate of Pakistan. Error correction term of given model is significant and negative, but overall model is insignificant. 


\section{Stability of model}

The stability of short run model in the given sample size is estimated by using the cumulative sum (CUSUM) and CUSUM of square test on the recursive residuals. According to Brown, Durbin, and Evans (1975) to identify an organized change in coefficients CUSUM is used, and CUSUM square is used to identify an abrupt change in the constancy of regression coefficients.

(The straight lines represent critical bounds at 5\% significance level)

Figure: 1 Test of Stability
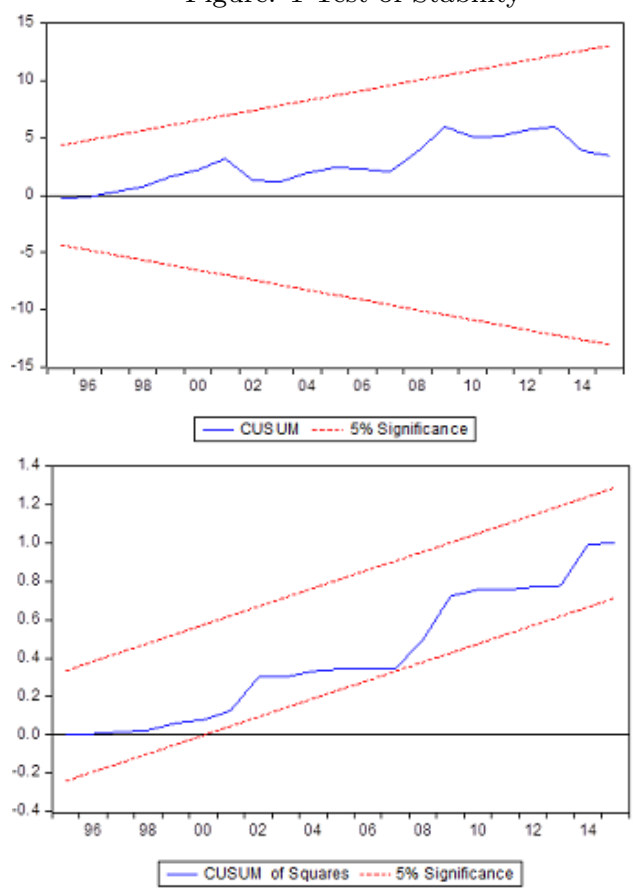

According to above results, there is no structural instability in the residuals of selected short run model, as above figures represent the results of both CUSUM and CUSUM of the square test are lie within the critical bound at 5\% (Raza, Jawaid, Afshan, \& Karim, 2015).

\section{Causality Analysis}

The direction of causality between exchange rate (dependent) and interest rate (independent variable) is analyzed by Granger (1969) results of causality analysis of selected model is given below according to given results there is unidirectional causality from interest rate (IR) to exchange rate (LER) except at lag-5 there is no granger causality between these two variables, it means interest rate of Pakistan does cause exchange rate of Pakistan in 
next 1,2,3,4 and 5 years (at lag 1,2,3,4 and 5) according to results IR (Interest Rate) and CPI (Inflation) granger cause LER (Exchange Rate) as rejecting test hypothesis of does not Granger Cause, having probability of F-Statistics less than .05(5\%).

Table 5

Granger Causality

\begin{tabular}{lccc}
\hline Variables & Lags & F-Statistic & Prob. \\
\hline IR does not Granger Cause LER & 1.000 & 9.389 & $* 0.0044$ \\
LER does not Granger Cause IR & & 1.103 & 0.302 \\
IR does not Granger Cause LER & 2.000 & 4.778 & $* 0.0161$ \\
LER does not Granger Cause IR & & 0.432 & 0.653 \\
IR does not Granger Cause LER & \multirow{2}{*}{3.000} & 3.958 & $* 0.0189$ \\
LER does not Granger Cause IR & & 0.235 & 0.871 \\
IR does not Granger Cause LER & \multirow{4}{*}{4.000} & 2.633 & $* 0.0604$ \\
LER does not Granger Cause IR & & 0.164 & 0.955 \\
IR does not Granger Cause LER & 5.000 & 1.911 & 0.137 \\
LER does not Granger Cause IR & & 0.134 & 0.983 \\
\hline
\end{tabular}

Source: Author's estimations

\section{Variance Decomposition}

Table 6

Variance Decomposition

\begin{tabular}{cccccc}
\hline Period & S.E. & LER & IR & CPI & GDP \\
\hline \multicolumn{7}{c}{ Variance } & Decomposition of LER: & & & \\
1 & 0.049 & 100.000 & 0.000 & 0.000 & 0.000 \\
2 & 0.072 & 92.562 & 6.778 & 0.521 & 0.139 \\
3 & 0.095 & 81.835 & 16.122 & 1.819 & 0.224 \\
4 & 0.117 & 72.186 & 24.084 & 3.520 & 0.210 \\
5 & 0.139 & 64.684 & 29.897 & 5.262 & 0.156 \\
6 & 0.160 & 59.105 & 33.928 & 6.842 & 0.125 \\
7 & 0.180 & 54.967 & 36.701 & 8.171 & 0.161 \\
8 & 0.198 & 51.840 & 38.636 & 9.229 & 0.294 \\
9 & 0.215 & 49.401 & 40.029 & 10.029 & 0.542 \\
10 & 0.231 & 47.416 & 41.071 & 10.597 & 0.916 \\
& & & & & \\
Variance Decomposition of IR: & & & \\
1 & 1.903 & 1.530 & 98.470 & 0.000 & 0.000 \\
2 & 2.595 & 1.828 & 96.249 & 1.607 & 0.315 \\
3 & 3.037 & 2.061 & 93.152 & 3.630 & 1.157 \\
4 & 3.337 & 2.231 & 89.909 & 5.276 & 2.584 \\
5 & 3.551 & 2.339 & 86.748 & 6.323 & 4.590 \\
6 & 3.714 & 2.390 & 83.694 & 6.817 & 7.099 \\
7 & 3.850 & 2.390 & 80.712 & 6.903 & 9.994 \\
8 & 3.973 & 2.349 & 77.771 & 6.739 & 13.141 \\
9 & 4.093 & 2.278 & 74.860 & 6.448 & 16.414 \\
10 & 4.214 & 2.185 & 71.991 & 6.109 & 19.716 \\
\hline
\end{tabular}

Cholesky Ordering: LER IR

To analyze the strength of the causal relationship between exchange rate and interest rate, error variance decomposition method is used under VAR system, it provides the magnitude of the estimated error variance for selected series with each exogenous variable over the 
different time period. Table:6 provides the result of variance decomposition analysis. According to VAR lag selection criteria maximum, 1 lag was selected for given model. Results show that variation in the exchange rate is $100 \%$ explained by own sake in the period 1 . In period 2 variance in the exchange rate is $92.56 \%$ is explained by own shock, $6.77 \%$ is explained by shock in interest rate, $0.52 \%$ and $0.13 \%$ is explained by shocks in inflation(CPI) and economic growth(GDP). Respectively in period 5 variance in the exchange rate of Pakistan has explained $64.68 \%$ by own shock, $29.89 \%$ variance in the exchange rate is explained by shock in the interest rate of Pakistan, $5.26 \%$ and $0.15 \%$ variances are explained by shocks in inflation and economic growth of Pakistan. Finally, in period 10 exchange rate own shock variance is $47.41 \%$, interest rate shock variance is $41.07 \%$ and variances due to the shocks of inflation and economic growth are $10.59 \%$ and $0.91 \%$ respectively.

\section{Conclusion and Recommendations}

\section{Conclusion}

Pakistan is a developing country and economic performance of Pakistan since 2008 has been very unfortunate because of terrorism, ruthless energy crisis and poor law and order situation in the country. In such terrible conditions, both exchange rate and interest rate are very significant features for the economy of countries like Pakistan. Exchange rate and interest rate both play an important role to manage the monetary policy of any country. The principal attention of this study to approximate the relationship between exchange rate and interest rate of Pakistan from the time period 1980 to 2015. The results of the study suggest that there is a negative relationship between interest rate and the exchange rate of Pakistan in the long run and no relationship in the short run, after controlling the impact of inflation (CPI) and economic growth (GDP).

In case of an increase in interest rate of Pakistan the exchange rate of Pak Rupee against the US Dollar will decrease, because of the high inflation value of Pak Rupee will depreciate against the USD (Depreciation of PKR), on the other hand decrease in interest rate will also decrease the exchange rate of Pak Rupee against the USD as appreciation of Polk Rupee.

Current interest rate $(5.75 \%)$ is the lowest interest rate in the history of Pakistan; similarly, recent performance of Pakistan Stock Exchange is at its best breaking the record of trading because of positive indicators of Pakistan's economy and China-Pakistan Economic Corridor (CPEC). According to a recent report by the International Organization "Emerging Markets", Pakistan has declared the "Best Country for Infrastructure Development in South Asia", according to IMF/World Bank Annual meeting 2016.

\section{Recommendation}

This study is regarding the relationship between exchange rate and interest rate of Pakistan and both these variables are the key factors of monetary policy of Pakistan and the current economy is facing the difficulty of mounting exchange rate, which has severely affected our balance of payment because of costly imports. As positive relationships between exchange 
rate and the interest rate are estimated, so the government of Pakistan should adopt such policies to increase the interest rate (Discount rate), to increase exchange rate, but also controlling the inflation too.

- The government of Pakistan should control the situation of law and order to attract the foreign investment, which will increase the inflow of foreign currencies that would diminish the value of foreign currencies and reinforce the value of Pakistani rupee.

- Pakistan should progress research and development and better infrastructure and wipe up energy crisis to get healthier its production capacity and to enhance international market share with the support of better quality export to generate revenue from international market and also reduce the consumption of foreign products especially luxury items to control the outflow of (USD) or foreign currencies by managing our imports.

- Pakistan should improve its financial market to magnetize foreign and local investment in the financial asset as currently, Pakistan is going to issue Euro bond this will improve the confidence of investors and the overall financial market will get better, this recommendation is useful in the short run.

\section{Future Recommendation}

The recommendation can be made in many different conducts for further improvement for future researchers, students, and policymakers.

- In this research the selected sample country is only Pakistan, this study can be examined in other countries, especially Asian countries to compare the overall economic situation of Asia for further betterment.

- In this study relationship is only examined between exchange rate and interest rate, can use other economic indicators too, as foreign direct investment, imports, government spending, domestic investment and money supply. 


\section{References}

Ahmad, E., \& Ali, S. A. (1999). Exchange rate and inflation dynamics. The Pakistan Development Review, 38(3), 235-251.

Arif, I., \& Suleman, T. (2017). Terrorism and stock market linkages: An empirical study from a front-line state. Global Business Review, 18(2), 1-14.

Azid, T., Jamil, M., Kousar, A., \& Kemal, M. A. (2005). Impact of exchange rate volatility on growth and economic performance: A case study of Pakistan, 1973-2003. The Pakistan Development Review, 44(4), 749-775.

Bahmani-Oskooee, M., \& Goswami, G. G. (2005). Black market exchange rates and purchasing power parity in emerging economies. Emerging Markets Finance and Trade, 41(3), 37-52.

Baldwin, J. R., \& Yan, B. (2007). Exchange rate cycles and Canada/US manufacturing prices. Review of World Economics, $143(3), 508-533$.

Brown, R. L., Durbin, J., \& Evans, J. M. (1975). Techniques for testing the constancy of regression relationships over time. Journal of the Royal Statistical Society. Series B (Methodological), 37(2), 149-192.

Colantone, I. (2012). Trade openness, real exchange rates and job reallocation: Evidence from belgium. Review of World Economics, 148(4), 669-706.

Dickey, D. A., \& Fuller, W. A. (1979). Distribution of the estimators for autoregressive time series with a unit root. Journal of the American Statistical Association, $74(366 \mathrm{a})$, 427-431.

Duttagupta, R., \& Tolosa, G. (2007). Fiscal discipline and exchange rate arrangements: Evidence from the Caribbean. Emerging Markets Finance and Trade, 43(6), 87-112.

Greenaway, D., Kneller, R., \& Zhang, X. (2012). The effect of exchange rates on firm exports and the role of FDI. Review of World Economics, 148(3), 425-447.

Groen, J. J. (2005). Exchange rate predictability and monetary fundamentals in a small multi-country panel. Journal of Money, Credit, and Banking, 37(3), 495-516.

Harvey, J. T. (2005). Post keynesian versus neoclassical explanations of exchange rate movements: A short look at the long run. Journal of Post Keynesian Economics, $28(2), 161-179$.

Haug, A. A. (2002). Temporal aggregation and the power of cointegration tests: A Monte Carlo study. Oxford Bulletin of Economics and Statistics, 64(4), 399-412.

Helmut, H. (2003). On the (nonlinear) relationship between exchange rate uncertainty and trade-an investigation of US trade figures in the group of seven. Review of World Economics, 139 (4), 650-682.

Kandil, M., \& Mirzaie, I. (2005). The effects of exchange rate fluctuations on output and prices: Evidence from developing countries. The Journal of Developing Areas, 38(2), 189-219.

Larsson, A. S. (2004). The swedish real exchange rate under different currency regimes. Review of World Economics, 140(4), 706-727.

Lewis, V. J. (2007). Productivity and the euro-dollar real exchange rate. Review of World Economics, 143(2), 324-348. 
Li, X. (2004). Trade liberalization and real exchange rate movement. IMF Economic Review, $51(3)$, 553-584.

Machnes, Y. (2006). The trading volume of currency options and the spot exchange rate. Emerging Markets Finance and Trade, 42(3), 91-97.

Mankiw, N. G. (2004). Principles of macroeconomics. Thomson/South-Western, Mason, $\mathrm{OH}$.

Narayan, P. K., \& Smyth, R. (2006). The dynamic relationship between real exchange rates, real interest rates and foreign exchange reserves: Empirical evidence from China. Applied Financial Economics, 16(9), 639-651.

Nathan, T. M., Liew, V., \& Wong, W.-K. (2016). Disaggregated energy consumption and sectoral outputs in Thailand: ARDL bound testing approach. Journal of Management Sciences, 3(1), 34-46.

Peridy, N. (2003). Exchange rate volatility, sectoral trade, and the aggregation bias. Review of World Economics, $139(3), 389-418$.

Pesaran, M. H., \& Shin, Y. (1998). An autoregressive distributed-lag modelling approach to cointegration analysis. Econometric Society Monographs, 31, 371-413.

Pesaran, M. H., Shin, Y., \& Smith, R. J. (2000). Structural analysis of vector error correction models with exogenous I (1) variables. Journal of Econometrics, 97(2), 293-343.

Pesaran, M. H., Shin, Y., \& Smith, R. J. (2001). Bounds testing approaches to the analysis of level relationships. Journal of Applied Econometrics, 16 (3), 289-326.

Rahman, A. A., \& Basher, S. A. (2001). Real exchange rate behaviour and exchange rate misalignments in Bangladesh. The Bangladesh Development Studies, 27(2), 69-93.

Raza, S. A., Jawaid, S. T., Afshan, S., \& Karim, M. Z. A. (2015). Is stock market sensitive to foreign capital inflows and economic growth? Evidence from Pakistan. Journal of Chinese Economic and Foreign Trade Studies, 8(3), 142-164.

Rehman, H. U., \& Afzal, M. (2003). The black market exchange rate and stability of demand for money in pakistan: A cointegration analysis. Pakistan Economic and Social Review, 41(1), 13-28.

Scott Hacker, R., Karlsson, H. K., \& Maansson, K. (2012). The relationship between exchange rates and interest rate differentials: A wavelet approach. The World Economy, 35(9), 1162-1185.

Shah, N. (2016). The impact of working capital management on firms profitability in different business cycles: Evidence from Pakistan. Journal of Finance 83 Economics Research, 1(1), 58-70.

Sharif, A., Raza, S. A., et al. (2016). Dynamic relationship between urbanization, energy consumption and environmental degradation in pakistan: Evidence from structure break testing. Journal of Management Sciences, 3(1), 01-21.

Taguchi, H. (2007). The post-crisis exchange rate management in selected East Asian countries. The Journal of Developing Areas, 40(2), 19-34.

Zakaria, M., \& Ahmad, E. (2009). Productivity shocks and nominal exchange rate variability: A Case Study of Pakistan. Journal of Economic Integration, 24 (1), 175-189. 